\title{
TAJEMNICA WCIELENIA W MOWACH ŚW. PIOTRA CHRYzOLOGA
}

Nie ma szczęścia Piotr Chryzolog, gdy chodzi o opracowania swojego nauczania przez współczesnych badaczy. Wobec daleko zaawansowanych badań nad doktryną św. Ambrożego, czy św. Augustyna, teologia zawarta w 183 kazaniach biskupa Rawenny pozostaje nadal nieznana, oczekująca na gruntowną analizę. O braku zainteresowania i nieznajomości nauki tego Doktora Kościoła niech świadczy fakt, iż monumentalne dzieło A. Grillmeiera ogranicza informację na temat chrystologii Chryzologa do lapidarnej wzmianki zawartej w jednym, jedynym przypisie ${ }^{1}$, natomiast M. Simonetti, redaktor wielotomowej antologii Letteratura cristiana antica, zupełnie pominął autora 183 kazań? ! Osoba biskupa Rawenny została przedstawiona również bardzo powierzchownie w opublikowanej przez „Augustinianum” najnowszym wydaniu Patrologii. W czterotomowej edycji, liczącej ponad 2600 stron, Piotrowi Chryzologowi poświęcono zaledwie dwie! ${ }^{3}$ I chociaż prawdą jest, iż doktryna biskupa Rawenny, nie posiada dla historii teologii tak wielkiego znaczenia, jak nauczanie Augustyna czy Leona Wielkiego, to jednak wydaje się słuszne, aby doktryna tego biskupa, którego tradycja okrzyknęła Złotosłowym, była bardziej znana.

Zarysowana sytuacja, nie oznacza bynajmniej braku jakichkolwiek badań nad teologią tego Doktora Kościoła. Tajemnica wcielenia w jego nauczaniu należy do jednego z najlepiej opracowanych zagadnień. Rezultaty przeprowadzonych badań, zostały przedstawione w studiach poświęconych jego chrystologii. Prace R. Benericettiego ${ }^{4}$, R. Mc Glynna ${ }^{5}$ i G. Sessa ${ }^{6}$ zgodnie podkreślają, iż tajemnica wcielenia należy do najistotniejszych tematów w teologii Piotra

${ }^{1}$ Por. Le Christ dans la tradition chrétienne. De l'âge apostolique à Chalcédoine (451), Paris 1973, 529, n. 30.

2 Por. Letteratura cristiana antica, voll. I-III, Casale Monferrato 1996.

3 Por. B. Studer, Pietro Crisologo, w: AA. VV., Patrologia, III, Genova 1995, 544-545.

${ }^{4}$ Por. R. Benericetti, La cristologia di S. Pier Crisologo, Romae 1995.

${ }^{5}$ Por. R. Mc Glynn, The Incarnation in the Sermons of Saint Peter Chrysologus, Chicago 1956.

${ }^{6}$ Por. G. Sessa, La dottrina cristologica di san Pietro Crisologo, Pozzuoli 1944. 
Chryzologa. O niezwykłej roli, jaką odgrywał on w doktrynie biskupa Rawenny, świadczy nie tylko duża ilość kazań poświęconych temu zagadnieniu, lecz również specyficzny charakter jego teologii, która w tajemnicy wcielenia znajdowała mocny punkt oparcia. Homilie Złotosłowego Kaznodziei ukazują nam bowiem ścisłe powiązanie interesującego nas tematu z soteriologią, mariologią, antropologią, a nawet $\mathrm{z}$ sakramentologią.

Przystępując do prezentacji tajemnicy wcielenia w nauczaniu Piotra Chryzologa, należy zauważyć, że doktryna przedstawiona w 183 homiliach jest tak bogata i obszerna, że jej wyczerpujące przedstawienie przekracza ramy niniejszego artykułu i domaga się odrębnego, monograficznego studium. Powyższe opracowanie ma charakter szkicu, który w syntetyczny sposób usiłuje przedstawić zasadnicze wątki doktryny o wcieleniu, obecne w nauczaniu Piotra Chryzologa. Mamy nadzieję, iż niniejszy przyczynek wzbudzi zainteresowanie spuścizną biskupa Rawenny i zaowocuje nowymi badaniami, podjętymi również przez polskich patrologów.

\section{TAJEMNICA SYNA BOŻEGO}

Zanim jednak przejdziemy do omówienia tajemnicy Słowa, które stało się ciałem, należy przedstawić Osobę Bożego Syna w tajemnicy Trójcy Świętej. Tajemnica ta, została najpełniej zarysowana w homiliach poświęconych Symbolowi wiary, wygłaszanych do katechumenów w czasie wielkopostnego przygotowywania się do sakramentu chrztu.

1. Syn Boży odwiecznie rodzony z Ojca. Należy zauważyć, że Piotr Chryzolog wielokrotnie podkreśla, iż jedyny Syn Boży jest współwieczny Ojcu i od Niego pochodzi ${ }^{7}$. Pochodzenie to jest określane mianem rodzenia ${ }^{8}$. Ta szczególna relacja (generatio) zachodząca pomiędzy Pierwszą a Drugą Osobą Trójcy Świętej charakteryzuje wymienione osoby i sprawia, że o jednej z nich mówimy, iz jest Ojcem, o drugiej natomiast, że jest Synem: „Kto wyznał Ojca, wyznaje też i Syna, gdyż bez Syna nie można nazywać Go Ojcem" ". Ponieważ jednak rodzenie Syna z Ojca przekracza wymiary czasu i przestrzeni, dlatego też ,rodzenie Boga nie ma początku, ani końca, jest mu obce oddzielenie, gdyż Zrodzony (Syn) pozostaje w Rodzicu, a Rodzący nie przestaje trwać w Zrodzonym",10.

7 Por. Sermo 148bis, 1, CCL 24B, 924:"Quae enim tanto muneri tantaeque gratiae devotionis nostrae infirmitas respondebit, ubi unigenitus altissimo Patri cum Patre aeternitate perpetuus".

${ }^{8}$ Por. Sermo 61, 3, CCL 24, 342: „Discens Filium, genitus cognoscis esse de Patre, cognoscis de Patre genitum".

${ }^{9}$ Sermo 58, 3, CCL 24, 326.

${ }^{10}$ Sermo 61, 3, CCL 24, 342: „Generatio Dei initium non habet, nescit finem, non admittit excessum, quando in Genitore Genitus permanet, et in Genito Gignens permanere persistit”. 
Biskup Rawenny, wyjaśniając katechumenom pochodzenie Syna Bożego, przeciwstawiał się błędnym twierdzeniom arian. Jego zdaniem, istota herezji tkwiła w błędnej interpretacji pochodzenia Osób Boskich. Według Złotosłowego Kaznodziei, arianie interpretowali odwieczne i boskie rodzenie Syna posługując się kategoriami typowymi dla doświadczenia ziemskiego.

„Heretyk twierdzi: w jaki sposób jest ojcem jeśli nie wyprzedza w czasie? W jaki sposób synem jeśli nie pojawia się później? W jaki sposób ten kto rodzi, nie daje początku? W jaki sposób ten co jest rodzony nie bierze początku od tego, kto go rodzi? Tego naucza rozum, potwierdza to natura. Mylisz się heretyku!"11

Przypisywanie kategorii właściwych dla ziemskich narodzin, relacji zachodzącej pomiędzy Ojcem a Synem stanowiło o istocie błędu arian. Tego typu kategorie zakładały bowiem ruch i zmianę, a co za tym idzie, niedoskonałość, która sama w sobie jest sprzeczna z pojęciem Boga ${ }^{12}$. Przyjęcie takich kategorii pociągnęło za sobą zakwestionowanie nie tylko boskiej natury Syna, lecz również ojcostwa samego Boga ${ }^{13}$. Bóg, zauważa Piotr Chryzolog, jest poza czasem, a to implikuje niezmienność, stałość i wieczność. Dlatego też rodzeniu Syna z Ojca nie towarzyszy jakaś zmiana czy wzrost, gdyż jest ono odwieczne ${ }^{14}$. Wynika stąd, że Syn, podobnie jak Ojciec, jest odwieczny.

2. Syn współistotny Ojcu. Konsekwencją odwiecznego rodzenia Syna z Ojca jest dzielenie tej samej boskiej natury. Syn jest współistotny Ojcu, dlatego też dzieli tę samą odwieczną substancję. Pomiędzy Ojcem a Synem nie ma rozdzielenia czy separacji, gdyż relację tę charakteryzuje immanencja.

„Zrodzony pozostaje w Rodzicu, a w Zrodzonym, Ten, który rodzi, na co zwraca uwagę sam Pan Zbawiciel, «Ja jestem w Ojcu, a Ojciec we mnie»?"15

Immanencja, podkreślona przez Piotra Chryzologa, uwydatnia współistotność natur Ojca i Syna.

${ }^{11}$ Sermo 60, 4, CCL 24, 337: „Sed dicit haereticus: quomodo pater, si non praecedit? Quomodo filius, si non sequitur? Quomodo non dat initium, qui generat? Quomodo qui generatur principium a generante non sumit? Hoc ratio docet, hoc natura probat. Erras haeretice!”

12 Por. Sermo 60, 4, CCL 24, 336-337: „Qui credit Patrem et Filium, aetates non sentiat, gradus non cogitet, non tempora suspici etur, non conceptum quaerat, nesciat partum. Qui deum credit, divina confessus est, non humana".

13 Por. Sermo 62, 6, CCL 24, 348: „Semper ergo Filium fuisse crede, ne Patrem semper non fuisse blasphemes”; Sermo 61, 3, CCL 24, 342: „Quem Deum confessus es, crede Patrem, ut credens Patrem esse Filium discas: Discens Filium, genitum cognoscis esse de Patre, conoscis de Patre genitum".

14 Por. Sermo 62, 6, CCL 24, 348: „Quod si Pater tempus non capit, Filius initium nescit”.

15 Por. Sermo 61, 3, CCL 24, 342.,,Generatio Dei initium non habet, nescit finem, non admittit excessum, quando in genitore genitus permanet, et in genito gignens permanere persistit, dicente ipso domino: Ego in Patre, et Pater in me". 


\section{POCZĘCIE CHRYSTUSA}

1. Przygotowanie Maryi na poczęcie Jezusa. Kazania, w których biskup Rawenny wyjaśnia scenę Zwiastowania, zdają się podkreślać fakt, iż słowom pozdrowienia anielskiego (Ave, gratia plena), towarzyszy udzielanie Bożej łaski Dziewicy Maryi. Łaska, uświęcając Błogosławioną Dziewicę, przygotowuje Ją do wydarzenia wcielenia. Słowa archanioła Gabriela, skierowane do pokornej Służebnicy Pańskiej, otrzymują w homilii 143 następującą inerpretację:

„«Bądź pozdrowiona, łaski pełna, Pan z Tobą. Bądź podrowiona», to znaczy przyjmij. Co? Dary łaski, a nie dar dziewictwa (pudoris). «Bądź podrowiona, łaski pełna». Oto łaska, która dała chwałę niebiosom, ziemi Boga, wiarę narodom, kres występkom, życiu porządek, obyczajom dyscyplinę. Tę łaskę, którą przyniósł anioł, przyjęła dziewica, mająca porodzić zbawienie wieków"16.

Udzielenie pełni łaski Dziewicy Maryi oznacza Jej uświęcenie. Maryi zostaje udzielona pełnia łask, która przygotowuje Ją na przyjęcie Syna Bożego ${ }^{17}$. Duch Święty, uświęcając Błogosławioną Dziewicę powoduje wzrost łaski w Jej duszy. Taki wniosek można wysnuć ze słów zawartych w kazaniu $142^{18}$. Jeżeli zatem w momencie Zwiastowania uświęcająca aktywność Ducha Świętego powoduje wzrost łaski, to czy oznaczałoby to, że Maryja jest święta przed momentem Zwiastowania, co więcej, jest święta, niepokalana, od początku swojego istnienia? Biskup Rawenny nie daje nam jasnej i jednoznacznej odpowiedzi ${ }^{19}$.

2. Poczęcie Jezusa przed „fiat” Maryi. Homilie biskupa Rawenny zawierają kilka sformułowań, które zdają się twierdzić, iż wcielenie dokonało się zanim jeszcze Maryja wypowiedziała swoje „fiat”. Kazanie 140, na przykład, ukazuje w tym samym momencie czasu dwa dokonujące się wydarzenia: pozdrowienie anioła oraz wcielenie:

16 Sermo 143, 4, CCL 24B, 872-873: „«Have, gratia plena, dominus tecum». Have, hoc est, accipe. Quid? Virtutis munera, non pudoris. Have gratia plena. Haec est gratia, quae dedit caelis gloriam, terris deum, fidem gentibus, finem vitiis, vitae ordinem, moribus disciplinam. Hanc gratiam detulit angelus, accepit virgo salutem saeculis redditura”.

17 Sermo 142, 2, CCL 24B, 863: „Denique ne tanto pondere caelestis fabricae in Maria subtilis nostri corporis arena subcumberet, et in virgine totius generis humani portatura fructum virga tenuis frangeretur".

18 Por. Sermo 142, 13, CCL 24B, 868: „Quae vocatura ab angelo domina, ipsa se cognoscit et confitetur ancillam, quia devotus animus infulis beneficiorum crescit ad obsequium, augetur ad gratiam, non ad arrogantiam prosilit, non ad superbiam pertumescit".

${ }_{19}$ Piotr Chryzolog, mówiąc o uświęceniu Maryi, rozumianym jako Jej przygotowanie na przyjęcie Syna Bożego, zdaje się reprezentować nurt wschodniej Tradycji, w której temat ten jest dobrze znany. Pojawia się on na przykład w pismach Cyryla z Jerozolimy, Grzegorza z Nazjanzu, Antypatera z Bostry, zob. B. Kochaniewicz, La Vergine Maria nei sermoni di san Pietro Crisologo, Roma 1998, 235-238. 
„«Pan z tobą». Co oznacza, że Pan jest w tobie? Przychodzi do ciebie, nie po to, aby odwiedzić, lecz wkracza w ciebie, poprzez nowe tajemnicze narodziny” ${ }^{20}$.

Ta sama homilia zawiera inny, nie mniej wymowny fragment: „Dziewica szybko czuje, że został przyjęty w Jej łonie Najwyższy Sędzia, podczas gdy wcześniej widziała i kontemplowała niebiańskiego posłańca ${ }^{\text {"2l }}$. Jak można zauważyć, świadoma modyfikacja znaczenia słów podrowienia anielskiego «Pan z Tobą» na «Pan w Tobie» oraz opis reakcji Błogosławionej Maryi na początkowe słowa Gabriela, upoważniają nas do wyrażenia hipotezy, twierdzącej, że wcielenie dokonało się wcześniej niż Maryja wypowiedziała swoje tak Bogu. Opinia ta, znajduje swoje potwierdzenie w innych kazaniach Piotra Chryzologa $a^{22}$.

\title{
3. Poczęcie Jezusa jako zaślubiny Boskiego Oblubieńca z Oblubienicą
} Maryją. Jednym $z$ charakterystycznych aspektów tajemnicy wcielenia jest temat zaślubin. Rozważana w takiej perspektywie scena Zwiastowania, jest interpretowana przez Chryzologa jako przygotowanie Dziewicy przez anioła, pełniącego rolę drużby (metator), do zaślubin z Boskim Oblubieńcem. Niebieski Posłaniec, udzielając Maryi boskich darów, przygotowuje Ją na gody z Boskim Oblubieńcem:

\begin{abstract}
„Do Dziewicy posyła uskrzydlonego posłańca, aby wręczył skarb, przyjął posag, zaniósł łaskę; ma odebrać słowo wierności, dać dary za Jej cnotę, rozwiązać Dziewicy ręce. Szybko leci pośrednik, aby wybraną przez Boga Oblubienicę odwieść od ziemskiego wesela, nie żeby odebrać Józefowi małżonkę, lecz by Ją oddać Chrystusowi, któremu już w lonie matki od zaistnienia została dana w zastaw. Chrystus więc otrzymuje swą Oblubienicę, nie zabierając obcej, nie dokonując rozdzielenia, choć jednoczy się w ciele ze swym stworzeniem" ${ }^{\text {23 }}$.
\end{abstract}

Moment wcielenia został zintepretowany przez Chryzologa jako zaślubiny, a ściślej, jako gody, oblubieńcze zjednoczenie bóstwa z człowieczeństwem. Maryja jest oblubiennicą, natomiast Słowo-Oblubieńcem, którzy w momencie

${ }^{20}$ Sermo 140, 3, CCL 24B, 847: „ «Dominus tecum». Quid est in te dominus? Quia ad te non visitandi studio venit, sed in te novo nascendi inlabitur sacramento".

${ }^{21}$ Sermo 140, 5, CCL 24B, 848: „Mox sentit in se supernum suscipi iudicem, ubi ante iam caelestem vidit et contemplata est metatorem".

${ }_{22}$ Por. np. Sermo 143, 8, CCL 24B, 875: „Maria, inquit, «ut vidit angelum, turbata est in introitu eius». Turbata est caro, concussa sunt viscera, mens tremuit, tota cordis obstupuit altitudo, quia ingresso angelo virgo sensit divinitatis ingressum. Turbabatur humani corporis templum, et carnalis domicilii movebantur angustiae, cum se in virgineo pectore tota Dei conderetur magnitudo, et inter angustas pectoris metas tanta se maiestas artavit". Temat ten został przedstawiony szerzej w monograficznym studium poświęconym mariologii Piotra Chryzologa, zob. B. Kochaniewicz, La Vergine Maria nei sermoni di san Pietro Crisologo. Roma 1998, 85-93.

${ }^{23}$ Sermo 140, 2, CCL 24B, 846-847, thum. W. Kania, w: Teksty o Matce Bożej, II, Niepokalanów 1981, 129. 
wcielenia jednoczą się w akcie oblubieńczej miłości. Błogosławionej Dziewicy przysługują zatem tytuły Sponsa Dei oraz Sponsa Christi ${ }^{24}$. Piotr z Rawenny, jest jedynym pisarzem Kościoła Zachodniego, który przypisuje powyższe określenia Najświętszej Maryi Pannie.

4. Miejsce poczęcia (łono Maryi). Autor 183 kazań, opisując tajemnicę wcielenia, często odnosi się do dziewiczego łona Maryi, miejsca, w którym ta tajemnica się dokonała. Kaznodzieja posługuje się bogatym słownictwem, które podkreśla aspekt biologiczno-fizyczny poczęcia: pectus ${ }^{25}$, uterus $^{26}$, viscera $^{27}$, alveus $^{28}$. Natomiast inne sformułowania: aula regis ${ }^{29}$, hospitium uteri ${ }^{30}$, mansio uteri $^{31}$, templum Dei ${ }^{32}$, templum deitatis ${ }^{33}$, informują nas o tym, iż łono Błogosławionej Dziewicy stało się szczególnym miejscem zamieszkania Boga. Tajemnica Słowa, które staje się ciałem, interpretowana jako zaślubiny, znajduje również swoje odbicie w odpowiednim słownictwie, definiującym łono Maryi jako thalamus ${ }^{34}$, cubiculum pectoris $^{35}$. Natomiast aspekt dziewiczy poczęcia Chrystusa został wyrażony poprzez następujące określenia: corporis claustra $^{36}$, domicilium castitatis ${ }^{37}$, virginalis ianua ${ }^{38}$. Dokonana analiza pozwala stwierdzić, iż bogactwo używanych przez Złostosłowego biskupa określeń, pozwoliło na przedstawienie tajemnicy wcielenia w sposób jasny i obrazowy, czytelny dla wszystkich.

5. Dziewicze porodzenie Chrystusa. Podobnie jak poczęcie, również porodzenie Chrystusa ma charakter dziewiczy. Maryja, wydając na świat wcielone Słowo, nie doświadcza bólów porodu. Komentując tą tajemnicę Piotr Chryzolog stwierdza:

${ }^{24}$ Por. Sermo 140, 2, CCL 24B, 846-847: „Pervolat ad sponsam festinus interpres, ut a Dei sponsa humanae disponsationis arceat [...]. Christus ergo suam sponsam recipit, non praeripit alienam".

25 Por. Sermo 140, 5, CCL 24B, 848; Sermo 142, 5, CCL 24B, 865; Sermo 143, 8, CCL 24B, 875.

${ }^{26}$ Por. Sermo 117, 1, CCL 24A, 709; Sermo 140, 6, CCL 24B, 849; Sermo 140ter, 2, CCL 24B, 855; Sermo 141, 2, CCL 24B, 859; Sermo 142, 4, CCL 24B, 864; Sermo 143, 10, CCL 24B, 877; Sermo 144, 3, CCL 24B, 881, Sermo 145, 4, CCL 24B, 892; Sermo 146, 2, CCL 24B, 901.

\footnotetext{
28 Por. Sermo 141, 2, CCL 24B, 859.

${ }^{29}$ Por. Sermo 140ter, 2, CCL 24B, 855.

${ }^{30}$ Por. Sermo 145, 4, CCL 24B, 892.

31 Por. Sermo 147, CCL 24B, 909.

32 Por. Sermo 140ter, 2, CCL 24B, 855.

33 Por. Sermo 144. CCL 24B, 881.

${ }^{34}$ Por. Sermo 140ter, 2, CCL 24B, 855.

35 Por. Sermo 141, 2, CCL 24B, 859.

36 Por. Sermo 145, 4, CCL 24B, 892.

37 Por. Sermo 140ter, 2, CCL 24B, 855.

38 Por. Sermo 145, 4, CCL 24B, 892.
}

27 Por. Sermo 140, 4, CCL 24B, 847; Sermo 143, 8, CCL 24B, 875. 
„Dziewica poczyna, dziewica rodzi i pozostaje dziewicą. Ciało doświadcza łaski, a nie bólu, co więcej, rodząc doznaje wzrostu integralności, nie doznając jednocześnie uszczerbku fizycznego"39.

Przyjście Chrystusa na świat jawi się, jako objawienie zbawczej mocy Boga samego. Wydarzenie, które nie ma precedensów w historii ludzkości, zaznacza, iz Maryja jest wolna od bólów porodu, smutnego dziedzictwa będącego konsekwencją grzechu Ewy (Rdz. 3,16). Maryja jawi się jako nowa Ewa, która wydając na świat Zbawiciela, doświadcza potęgi wszechmocnego Boga.

Poczynając i rodząc Chrystusa, Błogosławiona Dziewica staje się matką, pozostając nadal dziewicą. W Niej łączą się w przedziwny sposób stany, które wzajemnie się wykluczają: dziewictwo i macierzyństwo. Nic więc dziwnego, że w jednym ze swoich kazań Piotr Chryzolog, rozważając wspomniane wydarzenie zapytuje: ,jeśli dziewica, w jaki sposób matka? Jeśli oblubienica, w jaki sposób rodzicielka?" 40

Wspomniana jedność przeciwieństw, realizująca się jedynie w osobie pokornej Służebnicy Pańskiej została wyrażona także poprzez często pojawiające się w kazaniach określenie virgo-mater ${ }^{41}$. Posługiwanie się tym dwuczłonowym pojęciem, okazało się pomocne w wyjaśnieniu tajemnicy dziewiczego macierzyństwa. Tajemnica ta, wyrażona również za pomocą łacińskiej triady: Virgo concipit, Virgo parturit, Virgo permanet ${ }^{42}$, jest głównym i najistotniejszym tematem mariologii Chryzologa. W oparciu o powyższy schemat biskup Rawenny konstruuje swoją doktrynę maryjną ${ }^{43}$. Należy w tym miejscu zauważyć, że pisma naszego Autora nie posiadają klasycznych terminów łacińskich, wyjaśniających Boże macierzyństwo: Dei genitrix, Mater Dei ${ }^{44}$. Aby wyrazić powyższy przywilej, Kaznodzieja posłużył się greckim terminem Theotókos ${ }^{45}$, nie pomijając bliskoznacznych terminów łacińskich: dominantis genetrix ${ }^{46}$, genitrix sancta $^{47}$, mater Christi ${ }^{48}$, mater sancta ${ }^{49}$.

${ }^{39}$ Sermo 117, 3, CCL 24B, 710: „Virgo concipit, virgo parturit, virgo permanet; ergo virtutis est caro conscia, non doloris, quae magis pariendo integritatis augumenta suscipit, damna doloris ignorat".

40 Sermo 142, 7, CCL 24B, 866: „Si virgo, quomodo mater? Si sponsa, genetrix quomodo?”

${ }^{41}$ Por. Sermo 58, 5, CCL 24, 327; Sermo 140ter, 2, CCL 24B, 855; Sermo 146, 3, CCL 24B, 902; Sermo 148, 3, CCL 24B, 920.

${ }^{42}$ Por. Sermo 62, 7, CCL 24, 349; Sermo 117, 1, CCL 24A, 536; Sermo 148, 1, CCL 24B, 917; Sermo 148bis, 3, CCL 24B, 925.

${ }^{43}$ Por. B. Kochaniewicz, La Vergine Maria nei sermoni di san Pietro Crisologo, Roma 1998, 102.

${ }^{44}$ Por. L. Gambero, Maria nel pensiero dei padri della Chiesa, Cinisello Balsamo 1996, 332; B. Kochaniewicz, Op. cit., 102.

${ }^{45}$ Por. Sermo 145, 6, CCL 24B, 894.

46 Por. Sermo 142, 2, CCL 24B, 863.

${ }^{47}$ Por. Sermo 49, 4, CCL 24, 272. 
Warto podkreślić, iż dziewicze zrodzenie Chrystusa, zosłaje ukazane jako uświęcenie Jego Matki. Syn Boży, przychodząc na świat, nie umniejszył integralności swej matki, lecz ją uświęcił, powodując wzrost cnót ${ }^{50}$.

„Przez narodziny Pana, dziewictwo nie uległo zniszczeniu, lecz zostało uświęcone, gdyż ono zrodziło Oblubieńca i Stróża swojej wstydliwości. Maria ofiaruje wierną posługę: brzemienna lecz panna, dziewica lecz matka, utraciła raczej bezdzietność (sterilitas) lecz nie dziewictwo. W Maryi są obecne: świętość, prawość, dziewictwo, czystość, integralność, wiara. Wszystkie cnoty są w Niej obecne, aby mężna Slużebnica mogła nosić w swym łonie Stworzyciela" ${ }^{51}$.

Piotr Chryzolog, komentując tajemnicę Bożego Narodzenia, ukazuje ją również w perspektywie zbawczej. Przyjście Chrystusa na świat, rozważane w tej perspektywie, ma na celu dokonanie naprawy tego, co poprzez grzech zostało zniszczone. Posłużenie się ideą rekapitulacji, pozwoliło biskupowi Piotrowi na wyrażenie następującej refleksji:

„Rodzi się z nienaruszonej niewiasty Chrystus, ponieważ było nie do pomyślenia, aby cnota została zrodzona przez przyjemność, czystość przez zmysłowość, nieskażoność poprzez zepsucie. Nie mógl zstąpić z niebios inaczej Ten, który poprzez nowy porządek narodzin, przyszedł zniszczyć panowanie śmierci”, ${ }^{52}$.

\section{WCIELENIE SYNA}

1. Posłannictwo Syna. Wydarzenie wcielenia zostało określone przez Doktora Kościoła, jako zstąpienie (descensio) Syna Bożego: „Zstąpił Pan z niebios na ziemię. Bóstwo zstąpiło do człowieczeństwa, zstąpiło niebiańskie panowanie w nasze zniewolenie" ${ }^{53}$. Pomimo zstąpienia Słowa z niebios na ziemię, misja ta nie oznacza Jego oddzielenia od Ojca. Ponieważ Ojciec jest zjednoczony z Synem, a Syn nieustannie zamieszkuje w Ojcu (J 8,28-29), mimo, że zstąpił na ziemię, pozostaje nadal zjednoczony z Ojcem ${ }^{54}$. Podkreślanie istniejącej jedności pomiędzy Ojcem a Synem, wynikało z konieczności przeciwstawienia się herezji arian, którzy negowali jedność natury Syna i Ojca.

Aby bronić prawdy o boskiej naturze Chrystusa, biskup Rawenny zwraca uwagę wiernych na tajemnicę podwójnego narodzenia Chrystusa, zaznaczając,

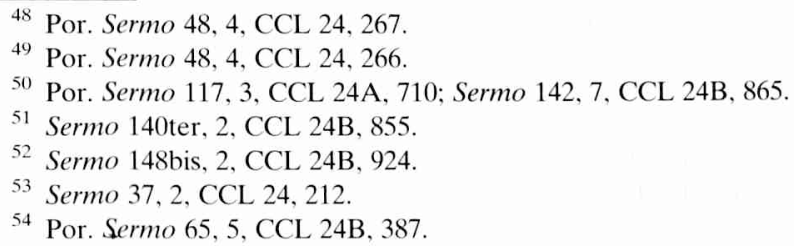


że zrodzenie Syna Bożego w czasie w niczym nie przekreśliło Jego odwiecznej relacji z Ojcem. Ziemskie poczęcie Syna w łonie Dziewicy Maryi jawi się jako objawienie niebiańskiej tajemnicy, odwiecznego rodzenia Syna z Ojca. Dlatego też w jednej ze swoich homilii Kaznodzieja wypowiada następujące słowa:

„Narodzenie Chrystusa było takie. Ewangelista nie powiedział „dokonało się tak”, lecz było takie, ponieważ narodzenie Chrystusa było u Ojca, kiedy został zrodzony z matki. Innymi słowy: to czym był, był nim zawsze; natomiast to czym się stał, to przyją: był Bogiem i stał się człowiekiem"55.

W przytoczonym fragmencie homilii, zarysowana tajemnica podwójnych narodzin Chrystusa, stoi na straży idei zjednoczenia Syna z Ojcem. Przyjęcie ludzkiej natury nie niweczy tej jedności. Ojciec pozostaje zjednoczony z Synem a Syn z Ojcem. U podstaw immanencji stoi jedność natury Osób Boskich. Podobna myśl zostaje wyrażona w komentarzu do Modlitwy Pańskiej:

„«Ojcze nasz, który jesteś w niebie». Ogarnia zdumienie: Chrystus z łona Boga Ojca wzywa matkę i uznaje ją na ziemi. Człowiek z łona matki wzywa Ojca i wyznaje, że jest w niebie ${ }^{56}$.

Chrystus stając się człowiekiem, pozostaje współistotny Bogu Ojcu. Natomiast w homilii 65 biskup Rawenny zauważa:

„(Chrystus) powiedział, że został posłany, aby ludzie wiedzieli, że Chrystus zstąpił $z$ niobios, lecz nie oddalił się od nieba" ${ }^{5}$.

Jak można zauważyć, podkreślenie jedności boskiej natury Syna i Ojca, miało za zadanie zaakcentownie prawdy o bóstwie Chrystusa ${ }^{58}$.

Wobec subordynacjonistycznej interpretacji tekstu Łk 1,32 ("Pan Bóg da Jemu tron jego praojca Dawida") prezentowanej przez zwolenników Ariusza, biskup Rawenny wyjaśnia prawdziwy sens tego fragmentu tekstu:

„«Pan Bóg da Jemu». Kto da i komu da? Jeśli nie Bóg człowiekowi, Bóstwo człowieczeństwu. Bóg Jemu da. Jaki Bóg? Z całą pewnością Słowo, które na początku było zawsze Bogiem. Komu da? Temu, który stał się ciałem i zamieszkał między nami [...] Bóg, który był w Chrystusie udzielił przyjętemu ciału, tego, co jako Bóg, zawsze posiadał"

55 Sermo 146, 2, CCL 24B, 901.

56 Sermo 72, 3, CCL 24A, 432; por. Sermo 88, 5, CCL 24A, 547; zob. B. Kochaniewicz, Bóg Ojciec i Maryja w tajemnicy podwójnych narodzin Chrystusa wedtug Piotra Chryzologa, w: „Salvatoris Mater” 1(1999) nr 2, 192.

57 Sermo 88, 5, CCL 24A, 388: „Missum se dixit, ut populi sciant de caelo venisse Christum, non recessisse de caelo".

${ }^{58}$ Por. Sermo 162, 5, CCL 24B, 1101.

${ }^{59}$ Por. Sermo 144, 7, CCL 24B, 883. 
W momencie wcielenia, stwierdza Chryzolog, Bóstwo przyjmując człowieczeństwo, udzieliło ludzkiej naturze królewskiej godności, daru, które posiadało od wieków.

2. Tajemnica podwójnych narodzin Chrystusa. Tajemnica dziewiczego poczęcia i narodzenia rozpatrywana w organicznej jedności, staje się dla Piotra Chryzologa odbiciem, epifanią odwiecznego rodzenia Słowa z Ojca. W kazaniu 146 Kaznodzieja wypowiada następujące słowa:

„,narodzenie Chrystusa było u Ojca, kiedy został zrodzony z matki. Innymi słowy: to czym był, był nim zawsze, natomiast to czym się stał, to przyjął: był Bogiem i stał się człowiekiem"60.

Jak można zauważyć, mysterium zostaje objawione za pomocą wydarzenia ziemskich narodzin. Stwierdzenie, iz Bóg rodzi Syna, objawiając Go poprzez doskonałości, wydaje się podkreślać analogię zachodzącą pomiędzy dwoma narodzinami: zarówno Ojciec rodząc Syna nie doświadcza boleści, jak i Maryja Dziewica rodzi Chrystusa w pokoju Bożego Ducha ${ }^{61}$.

Biskup Rawenny, rozważając tajemnicę narodzin Chrystusa, odkrywa jeszcze jedno podobieństwo: „tak jak Bóg Ojciec odwiecznie rodząc Syna nie doznaje jakiegoś uszczerbku i nie przestaje być Bogiem, tak Maryja, rodząc Syna, staje się matką, pozostając nadal dziewicą" ${ }^{62}$. Zarówno owe ziemskie, jak i to niebieskie porodzenie Syna Bożego ma charakter dziewiczy. Fragmenty kazań 58 i 117 zdają się potwierdzać naszą opinię:

„Dziewica poczyna, dziewica rodzi i pozostaje dziewicą. Ciało doświadcza łaski, a nie bólu, co więcej, rodząc, doznaje wzrostu integralności, nie doświadczając jednocześnie uszczerbku fizycznego ${ }^{63}$. Nie zna początku Syn, gdy Ojciec nie doznaje uszczerbku; gdzie rodzący nie starzeje się, nie wzrasta zrodzony. Wieczna i współwieczna jest substancja Ojca i Syna" ${ }^{64}$.

Akcent położony na podwójne narodziny Chrystusa, pozwolił Piotrowi z Rawenny skuteczniej bronić boskiej natury Chrystusa. Arianie, chociaż kwestionowali bóstwo Jezusa, to jednak nie negowali Jego dziewiczego narodzenia.

${ }^{60}$ Sermo 146, 2, CCL 24B, 901: „Christi, inquit, generatio sic erat». Non dixit: sic facta est, sed: «sic erat», quia Christi generatio erat apud Patrem, quando generabatur ex matre. Quod erat, semper erat, quod factum est hoc reddebat. Erat Deus, reddebatur homo".

${ }^{61}$ Por. Sermo 62, 6, CCL 24, 348; B. Kochaniewicz, Bóg Ojciec i Maryja w tajemnicy podwójnych narodzin Chrystusa wedtug Piotra Chryzologa, ,Salvatoris Mater” 1(1999) nr. 2, 193.

62 Por. B. Kochaniewicz, Bóg Ojciec a Maryja, art. cyt. s. 193.

63 Sermo 117, 3, CCL 24A, 710: ,Virgo concipit, virgo parturit, virgo permanet; ergo virtutis est caro conscia, non doloris, quae magis pariendo integritatis augumenta suscipit, damna doloris ignorat".

${ }^{64}$ Sermo 58, 3, CCL 24, 326-327: „Nescit inchoari Filius, quia deficere Pater nescit; nec crescit Genitus, ubi Genitor non senescit. Aeterna et coaeterna Patris et Filii substantia”. 
Dlatego też Chryzolog, opierając się na fakcie nie budzącym zastrzeżeń, (narodzenie Chrystusa z Dziewicy Maryi), wskazuje na tajemnicę odwiecznych narodzin Syna, podkreślając Jego boską naturę ${ }^{65}$.

3. Rzeczywistość wcielenia. Należy stwierdzić, że teologiczna refleksja Chryzologa nad osobą Chrystusa, nie zawiera filozoficznych pojęć, istotnych przy wyjaśnieniu tajemnicy wcielenia. Zamiast terminów natura, osoba biskup Rawenny posługuje się wyrażeniami: deitas, humanitas, Deus- homo, caroDeus. Jak zauważa G. Sessa, reakcja na błędne doktryny Arian i zwolenników Fotyna prowadzi Chryzologa do szczególnego zaakcentowania boskiej natury w Chrystusie. Cała Jego teologia jest podporządkowana zasadniczemu celowi: uwypuklić, podkreślić bóstwo Chrystusa. Nie można wykluczyć, że przyczyną braku zainteresowania zagadnieniem relacji pomiędzy boską osobą, a boska naturą, była konieczność obrony wiary przed herezją ariańską ${ }^{66}$.

Jak zauważa R. Benericetti, kazania biskupa Piotra charakteryzują się ubóstwem pojęć wyjaśniających zjednoczenie osobowe ${ }^{67}$. Jest to tym bardziej niezrozumiałe i trudne do wyjaśnienia, jeżeli uwzględni się fakt, że w tym samym czasie rozwija się kontrowersja spowodowana nauką Nestoriusza, a papież Leon Wielki, w oddalonym o kilkaset kilometrów Rzymie pisze listy i głosi kazania, w których wyraża swoje zaniepokojenie rozpowszechniającym się błędem. Kazania biskupa Rawenny, o dziwo, nie ukazują śladów zainteresowania współczesną kontrowersją, co więcej, użyta w nich terminologia wydaje się być nieadekwatna, do precyzyjnego wyjaśnienia tajemnicy zjednoczenia dwóch natur w osobie Chrystusa, tak istotnych wobec błędu nestorian.

Jak zauważa Benericetti, Piotr Chryzolog posługuje się jedynym określeniem, które wyraża jedność podmiotu w Chrystusie - unus Deus ${ }^{68}$. W kazaniu 59 znajdujemy następujące stwierdzenie:

„Pan Bóg, Bóg jedyny istnieje w Chrystusie, ponieważ cokolwiek istnieje, czy to bóstwo czy człowieczeństwo jest jednym Bogiem" ${ }^{\text {"99 }}$.

Wydaje się, że posługując się tym wyrażeniem, biskup Rawenny chciał podkreślić tożsamość Syna przed i po wcieleniu, to znaczy, że Słowo stając się ciałem, nie traci nic ze swojego bóstwa. Tę samą prawdę wyeksponował on w innym swoim kazaniu, w którym opierając się na tekście 1 Kor 6,17 („,Ten,

65 Por. B. Kochaniewicz, Bóg Ojciec a Maryja, art. cyt. s. 194.

${ }_{66}$ Por. R. Benericetti, La cristologia, dz. cyt. 107.

${ }^{67}$ Por. tamże.

68 Por. Benericetti, dz. cyt., 108.

${ }^{69}$ Sermo 59, 6, CCL 24, 332: „Dominus Deus Deus unus constat in Christo, quia quicquid est et deitate et humanitate, Deus unus est". Podobne wyrażenia spotykamy również w innych homiliach, np. Sermo 60, 5, CCL 24, 337; Sermo 81, 1, CCL 24A, 512; Sermo 143, 2, CCL 24B, 871; Sermo 145,9, CCL 24B, 897. 
kto się łączy z Panem jest z Nim jednym duchem”) zapytuje „kiedy Bóg jednoczy się z człowiekiem, w jaki sposób nie byłby jednym Bogiem?" ${ }^{70}$ Powyższe słowa podkreślają tożsamość Odwiecznego Słowa zarówno przed, jak i po Wcieleniu. Wydaje się, że akcent w chrystologii Chryzologa jest bardziej położony na odrębność i charakterystykę dwóch natur Chrytsusa, niż ich zjednoczenie w osobie Wcielonego Słowa. Należy stwierdzić, że zagadnienie jedności podmiotu w Chrystusie należy do słabej strony chrystologii Piotra Chryzologa. Ubóstwo adekwatnej terminologii zdaje się potwierdzać naszą opinię. Podobnego zdania jest także R. Benericetti ${ }^{71}$.

Wśród najczęściej używanych przez Złotosłowego Kaznodzieję określeń wyrażających dwie natury Chrystusa, należy wymienić następujące pary pojęć: Bóg-człowiek ${ }^{72}$, Bóg (bóstwo)-ciało ${ }^{73}$, Bóstwo-człowieczeństwo ${ }^{74}$. Analiza powyższych terminów, pojawiających się w kazaniach Chryzologa, ujawniła troskę biskupa Rawenny o wyrażenie, podkreślenie właściwości każdej z dwóch natur, z akcentem położonym na bóstwo Chrystusa. Zaakcentowanie bóstwa Chrystusa z jednej strony, i podkreślenie prawdziwości wcielenia z drugiej, miało doniosłe znaczenie rozwijanej w homiliach soteriologii. Syn Boży w momencie wcielenia przyjął całą ludzką naturę ${ }^{75}$. Jednocząc się z nią, udzielił jej zbawienia. Zakwestionowanie rzeczywistości wcielenia miałoby opłakane skutki dla zbawienia człowieka. Gdyby Słowo nie przyjęło kompletnej ludzkiej natury, nie zostałaby ona odkupiona, gdyż quod non est assumptum, non est sanatum. Dlatego zarówno narodziny, jak i śmierć Chrytusa są wydarzeniami realnymi. W przeciwnym wypadku, nie miałyby one żadnej wartości zbawczej. W jednym ze swoich kazań Piotr Chryzolog podkreśla rzeczywistość wcielenia w następujących słowach:

„Nie bój się Maryjo. Oto poczniesz w tonie (Łk 1,30). Ze względu na szacunek, można by było powiedzieć «oto poczniesz». Dlaczego jednak dodaje «w łonie»? Aby poczęcie było prawdziwe, a nie pozorne, aby porodzenie było rzeczywiste, a nie wyimaginowane. Ponieważ jak z Boga prawdziwego zrodzony jest prawdziwy Bóg, tak z prawdziwego poczęcia wyłania się prawda ludzkiego ciała"76.

${ }^{70}$ Sermo 145, 9, CCL 24B, 897: „«Qui se iungit domino, unus spiritus est». Et quomodo non, quando se iungit Deus homini, unus est Deus?".

${ }_{71}$ Por. Benericetti, La cristologia, dz. cyt., s. 108.

72 Sermo 100, 2, CCL 24A, 618; Sermo 125, 5, CCL 24A, 768; Sermo 142, 1, CCL 24B, 863; Sermo 144, 2, CCL 24B, 883; Sermo 146, 2, CCL 24B, 901; Sermo 148, 2, CCL 24B, 919; Sermo 160, 2, CCL 24B, 989-990.

73 Por. Sermo 62, 8, CCL 24, 349; Sermo 117, 1, CCL 24A, 709; Sermo 143, 5, CCL 24B, 873; Sermo 144, 7, CCL 24B, 883; Sermo 148, 1, CCL 24B, 918; Sermo 156, 5 CCL 24B, 972.

74 Por. Sermo 58, 5, CCL 24, 327; Sermo 144, 3, CCL 24B, 881; Sermo 156, 7, CCL 24B, 973.

75 Por. Sermo 141, 2, CCL 24B, 859: „Natus est in carne Christus, sed natus est de Spiritu Sancto; accepit hospitium carnis, sed de aula virginis, ut et veritas esset corporis humani, et de pollutione humani generis nil haberet".

76 Sermo 144, 4, CCL 24B, 881. 


\section{Aktywność Syna Bożego w momencie wcielenia. Chrystologia Piotra} Chryzologa obok swoich pięknych aspektów posiada pewne miejsca, niejasne, niezrozumiałe, które współczesnemu badaczowi przysparzają niemało kłopotu. Jednym z nich jest obecność i aktywność Ducha Świętego w momencie wcielenia. Analiza kazań pozwala nam na stwierdzenie, że czynnikiem sprawczym wcielenia jest Syn Boży, a nie Boski Paraklet. Co więcej, niektóre fragmenty homilii zdają się wskazywać, iż to, co ewangelie Łukasza i Mateusza przypisują Trzeciej Osobie Trójcy Świętej, Złotosłowy Kaznodzieja odnosi do Osoby Syna. Jako przykład niech posłuży fragment homilii 140 ter:
„Posłuchaj anioła, który mówi: «Duch Pański zstąpi na Ciebie i moc Najwyższego osłoni Cię» (Łk 1,35). Dzisiaj, bracia, nie zaistniało bóstwo, lecz ludzkość została odnowiona. Dzisiaj nie narodził się Chrystus dla siebie, lecz dla mnie. Pójdźcie do Niego, a zostaniecie oświeceni, oblicza wasze nie zapłoną wstydem ${ }^{77}$.

Wydaje się, że przytoczony tekst jest dowodem na to, iż biskup Rawenny, posługiwał się archaicznym typem chrystologii, określanym przez współczesnych patrologów jako Geistchristologie. Chrystologia duchowa, chociaż nie neguje istnienia Ducha Świętego, przypisuje rolę jaką odegrał w tajemnicy wcielenia osobie Słowa ${ }^{78}$. Zdaniem R. Benericettiego, kazania Piotra Chryzologa są przykładem takiej właśnie chrystologii ${ }^{79}$.

Aktywność Bożego Słowa podczas wcielenia, została przedstawiona za pośrednictwem obrazu Bożej ręki, kształtującej ciało. Posługując się tym symbolem, Piotr Chryzolog podkreślił istniejący związek pomiędzy wcieleniem a tajemnicą stworzenia człowieka. Ręka, która ukształtowała ciało pierwszego Adama, była tą samą, która kształtowała ciało drugiego Adama - Chrystusa w łonie Dziewicy Maryi. Wprowadzony do kazań obraz Bożej ręki, pozwolił Kaznodziei zaakcentować jedność natury Ojca i Syna, podkreślić aktywność Słowa w momencie wcielenia, jak również uwypuklić rzeczywistość tego wydarzenia. Ponadto, obraz tego typu okazał się niezwykle pomocny w zaakcentowaniu tożsamości odwiecznego Słowa-Stworzyciela człowieka oraz Wcielonego Syna- Zbawiciela rodzaju ludzkiego, jak również w podkreśleniu tożsamości aktywności wyrażonej w momencie stworzenia i zbawczego Wcielenia ${ }^{80}$.

Należy zauważyć, że powyższy obraz stanowił dobry argument w polemice wymierzonej przeciw doktrynie arian. Teza o inkompatybilności pomiędzy

77 Sermo 140ter, 1, CCL 24B, 854.

78 Por. Benericetti, dz. cyt. 178.

79 Por. Sermo 59, 7, CCL 24, 332; Sermo 60, 7, CCL 24, 338; zob. Benericetti, dz. cyt., 178. Należy zauważyć, że Benericetti do przykładów Geistchristologie zalicza również inne teksty Piotra Chryzologa; np. Sermo 57, 6, CCL 24, 321; Sermo 61, 5, CCL 24, 343; Sermo 62bis, 4, CCL 24, 354. Analiza tekstów, wymienionych exemplów skłania nas do wyrażenia opinii przeciwnej. Nie wydaje się, aby te przykłady przypisywały rolę Ducha Swiętego osobie Słowa.

${ }^{80}$ Por. Benericetti, dz. cyt., 179. 
Bogiem a ludzkim ciałem, dawała heretykom pretekst do zanegowania prawdy o wcieleniu. Biskup Rawenny, odpowiadając na tego typu argument zapytuje:

„czy odnowienie dzieła nie wychodzi na chwałę mistrza? Czy artyście nie przynosi honoru, gdy odnowi swe dzieło? Czy nie odnawia każdy swego dzieła, gdy się ono zestarzeje, nie podnosi, gdy upadnie, nie naprawia, gdy się zepsuje - nie chce go stracić. Coś podobnego jest w zrodzeniu przez Dziewicę - nie ma poniżenia Boga, a przychodzi zbawienie stworzenia. Skoro Bóg stworzył człowieka, któż mógłby Go zganić, za to, że go odnowił? Skoro słusznie wierzymy, że utworzył człowieka $\mathrm{z}$ mułu, czemu miałoby być niesłuszne, że go odnowił z ciała? Jakiż materiał jest szlachetniejszy - ciało czy muł?"81

Zastosowany przez biskupa Rawenny przykład Bożej ręki nie jest czymś zupełnie nowym. Pojawia się on po raz pierwszy w pismach św. Ireneusza z Lyonu. Należy jednak zauważyć, że, o ile autor Adversus haereses mówi od dwóch rękach Boga: Słowie i Duchu Świętym, które ulepiły Adama ${ }^{82}$, o tyle Piotr z Rawenny wymienia jedną rękę Boga, określając w ten sposób aktywność Bożego Syna. Taką opinię wyraził włoski patrolog R. Benericetti. Dokładna analiza pism Doktora Kościoła pozwaliła jednak na zweryfikowanie powyższej opinii. Okazało się bowiem, że Chryzologowi nie był również obcy obraz dwóch bożych rąk aktywnych podczas wcielenia. Stosownego przykładu dostarcza nam kazanie $141^{83}$. Powyższa opinia zmusza nas do ponownego postawienia pytania o funkcję i rolę Słowa i Ducha Świętego w tajemnicy wcielenia.

5. Zrodzony z Ducha Świętego. Chociaż niektóre teksty kazań zdają się potwierdzać opinię Benericettiego, co do obecności tzw. chrystologii duchowej w doktrynie biskupa z Rawenny, to jednak, oprócz tych fragmentów możemy znaleźć również i takie, które ukazując aktywność Bożego Ducha, zdają się kwestionować wspomnianą hipotezę. Komentarz do Credo, zawarty w homilii 57, podkreśla płodność Trzeciej Osoby:

„Kiedy Duch rodzi (generat), Dziewica wydaje na świat (parturit), dokonuje się całkowicie boskie a nie ludzkie wydarzenie" ${ }^{" 84}$.

Podobnie homilie 59 i 61 zawierają sformułowania, które wydają się podkreślać aktywność Ducha, a nie Słowa ${ }^{85}$. Niestety, niewielka ilość informacji zawarta

${ }^{81}$ Sermo 143, 9, CCL 24B, 876.

82 Por. Adversus haereses, V 1,3, SCh 153, 28-30; V 5,1, SCh 153, 62; V 6, 1, SCh 153, 72.

${ }^{83}$ Por. Sermo 141, 2-3, CCL 24B, 859.

${ }^{84}$ Por. Sermo 57, 6, CCL 24, 321: „ «Qui natus est de Spiritu Sancto et Maria virgine». Ubi Spiritus generat, virgo parturit, totum divinum geritur, nil humanum”.

${ }^{85}$ Por. Sermo 59, 7, CCL 24, 332: „Qui natus est de Spiritu Sancto et Maria virgine». Quid terrenum nascitur, ubi auctore Spiritu virgo vocatur in partu?”; Sermo 61, 5, CCL 24, 343: „"Qui natus est de Spiritu Sancto et Maria virgine». Spiritus et virgo copula terrena non est: est caeleste 
w homiliach, uniemożliwia znalezienie satysfakcjonującej odpowiedzi na postawione przez nas pytanie.

\section{OKREŚLENIA WCIELENIA}

1. Inhabitatio. Piotr Chryzolog opisuje tajemnicę wcielenia, używając pojęcia inhabitatio - zamieszkanie. W jednym ze swoich kazań, wyjaśniając znaczenie słów centuriona: „Panie nie jestem godzien abyś wszedł pod dach mój” zauważa:

„Dlaczego centurion zabrania Chrystusowi wejść pod swój dach, skoro widzi go zamieszkującego pod dachem jego ciała? Centurion widział w Chrystusie formę swojego ciała, lecz nie widział w Nim mąk swojego ciała. Chrystus narodził się w ciele, lecz z Ducha Świętego; przyjąć gościnę ciała, lecz z dziewiczej komnaty, aby posiadać prawdziwe ciało ludzkie". ${ }^{6}$

Wydaje się, że biskup Rawenny, aby wyjaśnić tajemnicę wcielenia, posługuje się obrazem zamieszkania duszy w ciele. Hospitium carnis oznacza ludzką naturę przyjętą przez Syna w momencie wcielenia. Ta sama idea została wyrażona także za pomocą innych terminów, jak habitaculum ${ }^{87}$ oraz templum $^{88}$.

Jak zauważa R. Benericetti, zjednoczenie Boga z człowieczeństwem zostało oddane również za pomocą terminu contubernium, określającego konkretnie zbiorowy namiot przeznaczony dla żołnierzy, a w sensie analogicznym oznacza współuczestnictwo $^{89}$. Tym niemniej Piotr Chryzolog jest świadomy, że powyższa idea zamieszkania nie jest w stanie wyjaśnić całego bogactwa tajemnicy wcielenia, dlatego używa także innych określeń.

2. Consortium. Innym pojęciem, pojawiającym się w kazaniach, jest consortium. Wyraża ono zaślubiny ludzkiej natury przez Boską Osobę Syna: Unigenitus (...) pro salute hominis humani corporis voluit subire consortium ${ }^{90}$. To

secretum. Hinc quod nascitur est divinum. Ergo quod natus est confitendum est, quomodo natus est tacendum".

${ }^{86}$ Sermo 15, 4, CCL 24, 96: „At nunc quid sic centurio tectum suum Christum vetat intrare, quem totum videt tectum sui corporis iam manere? Fratres, centurio iam videbat in Christo corporis sui formam, sed passiones in illo sui corporis non videbat. Natus est in carne Christo, sed natus est de Spiritu Sancto; accepit hospitium carnis, sed de aula virginis, ut et veritas esset corporis humani, et de pollutione humani generis nihil haberet".

${ }^{87}$ Por. Sermo 18, 6, CCL 24, 109.

${ }^{88}$ Por. Sermo 142, 1, CCL 24B, 863.

${ }^{89}$ Por. Sermo 6, 3, CCL 24, 45; zob. Benericetti, La cristologia di S. Pier Crisologo, dz. cyt. s. 94.

${ }^{90}$ Sermo 148bis, 1, CCL 24B, 924. 
samo słowo zostaje użyte, aby wyrazić zjednoczenie Boskiego Oblubieńca i Błogosławionej Dziewicy w momencie wcielenia: Deus et integritas est caeleste consortium; virginitas iuncta Christo copula est perfectae virtutis ${ }^{91}$. Należy zauważyć, że określenie consortium zostało również użyte przez Chryzologa przy wyjaśnianiu tajemnicy Mistycznego Ciała Chrystusa. Podobnie jak w wyżej wymienionych przykładach, pojęcie to określa jako małżeństwo, związek zachodzący pomiędzy Chrystusem a Kościołem ${ }^{92}$.

3. Indumentum. Kolejnym pojęciem wyrażającym tajemnicę wcielenia u Chryzologa jest indumentum - przyodzianie się. Ludzka natura przyjęta w momencie wcielenia została porównana przez Chryzologa do szaty. Rozważane w tym świetle mysterium Incarnationis pozwala na stwierdzenie, że Słowo przyodziało się szatą ludzkiej natury. Kazanie 117 Piotra Chryzologa wyraża tajemnicę wcielenia w taki właśnie sposób: „Stwórca ciała, przyjął odzienie ludzkiego ciała"93. Według opinii R. Benericettiego, idea przyodziania się odgrywa ważną rolę w chrystologii Piotra Chryzologa ${ }^{94}$.

4. Adsumere, suscipere. Moment wcielenia został również określony przez biskupa Rawenny pojęciem adsumptio, które wyraża przyjęcie przez Bożego Syna do jedności z sobą ludzkiego ciała ${ }^{95}$ bądź człowieka ${ }^{96}$. Obok terminu adsumere jest używane przez niego również inne pojęcie bliskoznaczne, mające na celu wyjaśnienie tajemnicy wcielenia: suscipere. To właśnie określenie pojawia się w kazaniu 50: „Chrystus przyszedł, aby wziąć na siebie (suscipere) nasze słabości, by udzielić nam swoich doskonałości ${ }^{, 97}$. Syn Boży w momencie wcielenia przyjmuje człowieczeństwo. Przyjmując zaś je, akceptuje również słabość, kruchość, przemijalność i śmiertelność ludzkiej natury.

5. Mixtio. Chryzolog dla wyrażenia tajemnicy Słowa, które stało się ciałem, posługuje się również czasownikiem miscere. Odnajdujemy je między innymi w homilii 142: Audistis, inaudita ratione in uno corpore Deum hominemque misceri $^{98}$. Wyrażenie to, które nadaje chrystologii biskupa Piotra specyficzne-

${ }^{91}$ Por. Sermo 146, 3, CCL 24B, 902-903.

92 Por. Sermo 164, 8, CCL 24B, 1014.

93 Sermo 117, 3, CCL 24A, 710: „Auctor carnis carnis sumeret indumentum”.

${ }^{94}$ Por. La cristologia di S. Pier Crisologo, 95.

95 Por. Sermo 148, 1, 24B, 918: „Manus, quae in nostrum plasma lutum dignanter adsumpsit, ad reparationem nostram dignanter adsumpsit et carnem".

96 Por. Sermo 85ter., 1, CCL 24A, 528. „Christus (..) hominem a peccatorum labe liberandum assumpsit".

${ }_{97}$ Por. Sermo 50, 1, CCL 24, 277: „Christus venit suscipere infirmitates nostras, et suas nobis conferre virtutes".

98 Sermo 142, 1, CCL 24B, 863; zob. także Sermo 15, 2, CCL 24, 36; Sermo 156, 5, CCL 24B, 972; Sermo 178, 4, CCL 24B, 1082. 
go kolorytu, pojawia się również w pismach Tertuliana, Augustyna i Leona Wielkiego. Jest pojęciem nieprecyzyjnym i dwuznacznym, ponieważ może budzić podejrzenia, że wcielenie było pewnego rodzaju zmieszaniem się w nową całość dwóch różnych rzeczywistości: boskiej i ludzkiej. Pomimo sporadycznie pojawiającego się $\mathrm{w}$ homiliach Chryzologa terminu mixtio, jego chrystologia jest daleka od błędu Eutychesa.

6. Commercium. Kolejnym pojęciem, które spotykamy w homiliach Złotosłowego, jest commercium. Wyrażenie to podkreśla zjednoczenie natury boskiej i ludzkiej w Chrystusie, i służy Chryzologowi do podkreślenia wynikających z niego zbawczych konsekwencji: uniżenia się boskiej natury i wywyższenia ludzkiej, przyjęcia słabości człowieka i obdarowania go bogactwem boskich darów. W ten sposób za pośrednictwem wymienionego pojęcia została wyrażona idea przebóstwienia:

„Oto przedziwna relacja między niebem a ziemią, pomiędzy ciałem a Bogiem, aby Bóg przemienił się w człowieka a człowiek w Boga, Pan w sługę, a sługa w syna; aby dokonało się w sposób cudowny jedna, jedyna perentela bóstwa i człowieczeństwa" 99 .

Zjednoczenie boskiej natury z ludzką dokonane w Chrystusie zaowocowało udzieleniem jej boskich prerogatyw. Ponieważ miejscem wcielenia jest łono Błogosławionej Dziewicy Maryi, dlatego również i Ona zostaje ogarnięta zbawczą aktywnością Boga ${ }^{100}$.

\section{PIOTR CHRYZOLOG WOBEC HEREZJI}

Kazania biskupa Rawenny odznaczają się mocno podkreślonym tonem apologetycznym. Chryzolog, jako pastor bonus ostrzega wiernych przed niebezpieczeństwem herezji, broni prawd wiary, wyjaśniając jej tajemnice, wykazuje błędy przeciwnika. Ponieważ zasadnicza część polemiki jest skierowana przeciwko herezjom chrystologicznym, dlatego omawiając tajemnicę wcielenia nie sposób pominąć milczeniem ten aspekt nauczania tego Doktora Kościoła.

99 Sermo 72, 3, CCL 24A, 430: ,... coeli et terrae, carnis et dei repente tantum posse provenire commercium, ut Deus in hominem, homo in Deum, dominus in servum, servus vertetur in filium, fieretque divinitatis et humanitatis ineffabili modo una et sempiterna cognatio".

${ }^{100}$ Por. Sermo 140, 6, CCL 24B, 848: Pavet coelum, tremunt angeli, creatura non sustinet, natura non sufficit, et una puellula sic Deum in sui pectoris capit, recipit, oblectat hospitio, ut pacem terris, caelis gloriam, ssalutem perditis, vitam mortuis, terrenis cum caelestibus parentelam, ipsius Dei cum carne commercium, pro ipsa domo exigat pensionem, pro ipso utero mercedem conquirat". 
1. Arianizm. Chryzolog w jednym ze swoich kazań wymienia nazwiska dwóch herezjarchów: Ariusza i Fotyna ${ }^{101}$. Chociaż arianizm nie był herezją chrystologiczną, lecz trynitarną, to jednak konsekwencje błędu Ariusza odbiły się również z całą swoją mocą na chrystologii. Zanegowanie jedności boskiej natury Ojca i Syna, uważanie Logosu za byt stworzony, prowadziło do odrzucenia boskiej natury w Chrystusie. Dlatego też Chryzolog, podejmując w swoich homiliach tematy chrystologiczne, nie mógł nie podejmować polemiki skierowanej przeciw herezji ariańskiej. O ile w homiliach 57-62bis Chryzolog wyjaśnia tajemnicę odwiecznego pochodzenia Syna od Ojca, o tyle w kazaniach 140148bis, przedstawiając tajemnicę wcielonego Słowa, skupił swoją uwagę na boskiej naturze Zbawiciela.

Pojawienie się imion Ariusza i Fotyna oraz silna kontrowersja antyariańska obecna w przepowiadaniu Chryzologa, zaskakują współczesnego badacza, nastawionego raczej na znalezienie śladów kontrowersji antynestoriańskiej bądź też polemiki wymierzonej przeciwko doktrynie Eutychesa. Takie oczekiwanie zdaje się być uzasadnione, jako że episkopat Piotra z Rawenny przypada na czas pomiędzy dwoma Soborami: Efeskim i Chalcedońskim. Tymczasem w kazaniach tego Doktora Kościoła zamiast wątków wymierzonych w naukę Nestoriusza, dominują akcenty antyariańskie. Wydaje się, że takie stanowisko było uwarunkowane obecnością w Rawennie, stolicy Cesarstwa Zachodniego, żołnierzy germańskich, wyznawców arianizmu, w wersji przekazanej im przez Wulfilę $^{102}$. W zaistniałej sytuacji, reakcja Chryzologa była całkowicie uzasadniona. Jako duszpasterz pragnął on ustrzec wiernych, powierzonych swojej pieczy, przed błędną doktryną.

2. Nestorianizm. Jak już to wyżej zostało powiedziane, mogłoby się wydawać, że kazania biskupa, którego działalność kaznodziejska przypada na czas kontrowersji antynestoriańskiej, będą obfitować w liczne przykłady polemiki wymierzonej przeciw herezji Nestoriusza, która, jak się wydaje, była mu znana. Świadczy o tym list Chryzologa adresowany do Eutychesa, w którym pojawia się imię patriarchy Konstantynopola. Ponadto opublikowana w latach pięćdziesiątych praca R. Mc Glynn, stwierdza obecność takiej polemiki w homiliach biskupa Rawenny.

Jednym z koronnych argumentów jest fragment kazania 145, w którym Chryzolog stwierdza: veniant, audiant, qui Graeco turbine Latinam nubilare

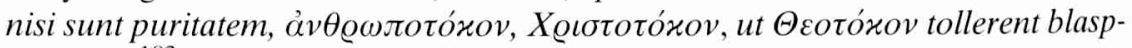
hemantes $^{103}$. Wymienione tutaj tytuły maryjne zdają się sugerować, że rzeczy-

101 Sermo 109, 4, CCL 24A, 675.

102 M. Meslin, Les Ariens d'Occident 335-440, Paris 1967, 308; M. Simonetti, Ulfila, II, 3527; S. Longosz, Wulfila propagator kultury chrześcijańskiej w starożytnej Mezji i Tracji, VoxP 3(1983) 125-159.

103 Sermo 145, 6, CCL 24B, 894. 
wiście chodzi tutaj o kontrowersję antynestoriańską. W taki właśnie sposób odczytuje ten fragment R. Mc Glynn ${ }^{104}$. Jednakże dokładna analiza całego kazania ujawnia nam, iż wymienione przez Chryzologa terminy, zostały wypowiedziane w kontekście polemiki antyariańskiej, a nie antynestoriańskiej ${ }^{105}$. Tytuł Theotokos, użyty w polemice skierowanej przeciw zwolennikom doktryny Ariusza, miał za zadanie podkreślić bóstwo Chrystusa. Podobną opinię wyraża również R. Benericetti ${ }^{106}$.

Pisma Ojców Kościoła świadczą, iż tytuły przypisywane Matce Najświętszej anthropotokos i Theotokos znane były na długo przed pojawieniem się herezji Nestoriusza. Pierwszy z wymienionych, jest już znany Grzegorzowi z Nyssy ${ }^{107}$. Ponadto, do wymienionych wyrażeń nawiązuje sam Nestoriusz, który, broniąc swojej pozycji w dziele Liber Heraclidis, stwierdza, iż tytuły Theoktokos i anthropotokos były używane przez heretyków: pierwszym z wymienionych posługiwali się apolinaryści, natomiast drugi był dobrze znany zwolennikom Fotyna $^{108}$. Warto również pamiętać, iż określenie Theotokos było szeroko stosowane przez Ojców Kościoła IV stulecia. Pojawia się ono w dziełach św. Ambrożego $^{109}$, św. Bazylego z Cezarei ${ }^{110}$, św. Cyryla z Jerozolimy ${ }^{111}$, św. Grzegorza z Nazjanzu, ${ }^{112}$ św. Grzegorza z Nyssy ${ }^{113}$. Na uwagę zasługuje fakt, iż tytuł ten pojawiał się także w niektórych pismach św. Atanazego, w kontekście polemiki antyariańskiej ${ }^{114}$.

Podobnie jak przedstawiony wyżej argument, tak również i inne sformułowane przez Mc Glynna hipotezy, okazują się nieprzekonujące. Amerykański autor stwierdza na przykład, iż Nestoriusz negował możliwość cierpienia i prawdziwej śmierci Chrystusa, co według niego wynikało z zakwestionowania doskonałego zjednoczenia dwóch natur w Chrystusie. Jak zauważa death and ultimate triumph of Christ is to be attributed to divine virtue $e^{115}$. Trudno się

${ }^{104}$ Por. R. MC Glynn, The Incarnation in the Sermons of Saint Peter Chrysologus, Chicago 1956, 80-81.

105 Zagadnienie to zostało szerzej przedstawione w pracy: B. Kochaniewicz, La Vergine Maria nei sermoni di san Pietro Crisologo, 289-292.

106 Por. La cristologia di s. Pier Crisologo, 175.

107 Por. Epistola III. PG 46. 1024.

108 Por. Liber Heraclidis, w: Testi Mariani del Primo Millenio, vol. 1, Roma 1988, 541-542.

109 Por. De virginibus, II, 2, 7, PL 16, 220B: „Quid nobilius Dei matre?”; M. Starowieyski, Tytut Theotokos w świadectwach przedefeskich, AnCr 16(1984) 409-449.

${ }^{110}$ Por. Homilia in sanctam Christi generationem, 5, PG 31, 1468B.

111 Por. Catechesis X 19, PG 33, 685A.

112 Por. Epistola CI, PG 37, 177C.

113 Por. De virginitate, 13, PG 46, 377D; S. Longosz, Bogarodzica w nauce Ojców Kapadockich, ,Salvatoris Mater” 2(2000) nr 2, 84-104.

114 Por. Oratio contra Arianos, III 29 i 33, PG 26, 385A i 393B; M. Starowieyski, Mariologia św. Atanazego, RTK 33(1976) z. 4, 109-132; J. Królikowski, Theotokos w teologii św. Atanazego, „Salvatoris Mater” 2(2000) nr 1, 56-73.

115 R. Mc Glynn, dz. cyt., 81. 
zgodzić z wymienioną opinią, tym bardziej, że jej autor nie podaje ani jednego tekstu, który by potwierdzał przedstawioną przez siebie hipotezę.

Wydaje się, że fragmenty homili, w których Chryzolog krytykuje opinie poddające w wątpliwość cierpienia Syna Bożego, należy raczej uznać za przejaw polemiki antyariańskiej. Dzięki badaniom Grillmeiera i Lieberta stało się oczywiste, że arianie opierając swoją chrystologię na schemacie Logos-sarx, negowali obecność duszy ludzkiej w Chrystusie. Jej funkcje spełniał Logos ${ }^{116}$. Nic więc dziwnego, że twierdzenie, jakoby boski Logos doświadczał nędzy ludzkiej natury, było dla arian nie do przyjęcia. „W jaki sposób, zapytywali zwolennicy Ariusza, Logos może uczestniczyć w życiu Ojca i doświadczać jednocześnie tego wszystkiego?"117 Aby przyjąć rzeczywistość wcielenia Logosu, arianie musieli zakwestionować Jego bóstwo. Było to logiczna konsekwencja wadliwej ariańskiej chrystologii ${ }^{118}$.

3. Apolinaryzm. W homiliach biskupa Rawenny możemy odnaleźć kilka fragmentów, które, jak się wydaje, mogły być skierowane przeciw zwolennikom doktryny Apolinarego. Kazanie 144 zawiera następujące słowa: „Jest zatem herezją, kto błędnie głosi, iż Chrystus przyjął ciało duchowe, a tak naprawdę to nie miał ciała, lecz udawał, że był człowiekiem"119. Informacja o ciele duchowym, które przyjąl Chrystus, pozwala nam przypuszczać, iż biskup Rawenny występował przeciwko herezji Apolinarego. Chociaż Apolinary, nie powiedział niczego na temat wspomnianego corpus aereum to jednak, jak zauważa A. Grillmeier, niektórzy autorzy zafałszowali jego doktrynę, oskarżając go o to, że nauczał o zstąpieniu na ziemię Chrystusa w ciele ${ }^{120}$. Dzieło Przeciw Apolinaremu Grzegorza z Nyssy potwierdza opinię niemieckiego uczonego. Grzegorz przedstawiając herezję biskupa Laodycei stwierdza, że wcielenie, według tej błędnej doktryny, miałoby się dokonać nie w łonie Dziewicy Maryi, lecz przed stworzeniem świata ${ }^{121}$. Jest zatem prawdopodobne, że przedstawiony powyżej fragment homilii Piotra Chryzologa stanowi polemikę skierowaną przeciw błędnej doktrynie Apolinarego ${ }^{122}$.

4. Piotr Chryzolog - apolinarystą? Niektóre wyrażenia i sformułowania, zawarte w homiliach Piotra Chryzologa budzą podejrzenia, czy aby biskup

116 J. Liebert, L'Incarnation. Des origines au Concile de Chalcédoine, Paris 1955, 115.

117 Athanasius, Contra Arianos ratio III, 27, PG·26, 381.

118 Por. B. Kochaniewicz, La Vergine Maria nei sermoni di s. Pier Crisologo, 270.

119 Sermo 144, 4, CCL 24B, 881: „Est ergo haeresis, quae Christum aereum corpus adsumpsisse mentitur, nec habuisse carnem, sed hominem simulasse confingit".

${ }_{120}$ Por. Grillmeier, Le Christ dans la Tradition, 260.

121 Por. Adversus Apollinarem, 15, PG 45, 1151.

122 Więcej na ten temat w pracy: B. Kochaniewicz, La Vergine Maria nei sermoni di san Pietro Crisologo, 292-295. 
Rawenny nie skłaniał się w swoim nauczaniu ku doktrynie apolinarystów. ${ }^{123}$ Widoczna predylekcja w posługiwaniu się schematami: Bóg-ciało, bóstwo-ciało ludzkie, bóstwo-człowieczeństwo wzbudza uzasadnione pytanie o obecność duszy Chrystusa. Homilia 102, zdaje się potwierdzać nasze obawy. Kaznodzieja, komentując słowa setnika z Kafarnaum wyjaśnia je w świetle tajemnicy wcielenia:

„«Nie jestem godzien abyś wszedł pod mój dach». Lecz Bóg, kiedy chce sprawia, że to co ludzkie staje się boskie, [...] nie gardzi ani zamieszkać w ciele, ani wejść pod dach naszego ciała" 124 .

Z przedstawionego tekstu wynika, iż Chryzolog opisał tajemnicę wcielenia, opierając się na przykładzie człowieka (dusza przebywająca w ciele), który pozwolił mu to dojść do konkluzji, iż Syn Boży, niczym dusza, zamieszkał w ludzkim ciele. W świetle przedstawionego exemplum łatwo dojść do wniosku, iż w momencie wcielenia Słowo przejęło funkcje ludzkiej duszy. Pojawia się pytanie: czy Piotr Chryzolog rzeczywiście akceptował tego typu schemat, który, co tu dużo mówić, był typowy dla chrystologii apolinarystów?

Fragmenty niektórych kazań zdają się przeczyć oskarżeniom biskupa Piotra o krypto-apolinaryzm. W homilii na uroczystość Zmartwychwstania Pańskiego Złotosłowy Kaznodzieja wypowiedział następujące słowa:

„Kiedy Zmartwychwstały Pan wszedł przez zamknięte drzwi, uczniowie nie wierzyli, że pojawił się On w ciele ludzkim, lecz podejrzewali, że powróciła jedynie dusza w wyobrażeniu cielesnym, jak to zwykle bywa, gdy śpiącym ukazują się wyobrażenia cielesne" ${ }^{125}$.

Informację o duszy Chrystusa przekazuje nam również kazanie $62^{126}$. Użyte przez Chryzologa sformułowanie suscepit animam potwierdza przyjęcie duszy ludzkiej przez Słowo w momencie wcielenia. A zatem doktryna Chryzologa jest ortodoksyjna. Słowo w chwili wcielenia, przyjęło nie tylko samo ciało, lecz również i ludzką duszę ${ }^{127}$.

123 C. Jenkins, Aspects of the Theology of St. Peter Chrysologus, „, The Church Quarterly Review” 103(1927), 248; G. Lucchesi, Note intorno a S. Pier Crisologo, „Studi Romagnoli” 3(1952), 104.

${ }^{124}$ Sermo 102, 6, CCL 24A, 634.

125 Sermo 81, 4, CCL 24A, 500.

126 Sermo 62,9, CCL 24, 350: „Sed ille de carne tua nasci voluit, tuis voluit uberibus occupari, iacere in tuo pectore, tuis voluit umeris baiulari, qui semper a te amari voluit, non timeri... Hinc est quod ad cor tuum venit, ad mentem tuam venit, suscepit animam tuam, quia animo, corde, corpore a te ab initio diligi perquisivit".

127 Do podobnego wniosku dochodzi również R. Benericetti. Por. La cristologia, 126-128. 


\section{ASPEKT ZBAWCZY WCIELENIA}

1. Wcielenie - kenozą Syna Bożego. W kazaniach biskupa Rawenny znajdujemy liczne fragmenty podkreślające zbawczy wymiar tajemnicy wcielenia. Warto zauważyć, iż dzieło zbawcze Chrystusa nie ogranicza się jedynie do wydarzenia Bożego Narodzenia, lecz rozciąga się na całe Jego życie, osiągając apogeum w tajemnicach Męki, Śmierci i Zmartwychwstania ${ }^{128}$. Ponieważ jednak znaczna część spośród zachowanych homilii Chryzologa dotyczy Wcielenia, zatem akcent w sposób naturalny przesuwa się na to właśnie mysterium.

Jednym $z$ ważnych aspektów omawianej tajemnnicy było uniżenie się i upokorzenie się Syna Bożego ${ }^{129}$. Słowo przyjmując ludzką naturę, wraz z jej przyjęciem, zaakceptowało wszystkie płynące stąd konsekwencje: akceptację bycia dzieckiem, doświadczenie trudu pracy, cierpienia, niesprawiedliwości aż po śmierć na krzyżu ${ }^{130}$. Należy jednak podkreślić, że przyjęcie ludzkiej natury nie spowodowało pomniejszenia, czy degradacji Boskiej Osoby Słowa ${ }^{131}$. Motywem wcielenia była naprawa i uleczenie skażonej na skutek grzechu ludzkiej natury. Słowo stało się ciałem, ut nascendo, corruptam redintegraret naturam ${ }^{132}$.

„Rodzący się Chrystus, nie znajduje miejsca w gospodzie, chociaż wszystko, co stworzone, jest dla Niego miejscem. Rodzi się jako pielgrzym, chociaż jest Panem całego świata, aby uczynić nas mieszkańcami niebieskiej ojczyzny" ${ }^{133}$.

Motywem Jego przyjścia na świat, zaznacza Piotr Chryzolog, było pragnienie zbawienia rodzaju ludzkiego ${ }^{134}$, zniszczenie imperium śmierci ${ }^{135}$, wewnętrzna odnowa człowieka ${ }^{136}$. Bóg zdecydował się przyjść do człowieka, po-

128 Sermo 80, 10, CCL 24B, 496: „Quod nascitur, quod patitur, quod resurgit, quod accipit, non est, non est necessitatis suae, nostrae est hoc salutis".

${ }^{129}$ Sermo 148bis, 3, CCL 24B, 925: „Quod hominis et dei filius se humiliavit in carne”.

130 Por. Sermo 144, 7, CCL 24B, 884: „Fatemur accepit; sed iste qui natus est, qui suscepit carnem, qui suscepit infantiam, qui cunabula pertulit, qui suscepit aetates, qui labores sustinuit, qui famem sensit, qui sitim passus est, qui tot iniuriarum genera non refugit, qui ascendit crucem, qui subiit mortem, qui intravit sepulchrum".

131 Por. Sermo 148, 1, CCL 24B, 917: „Nasci Christum non fuit necessitas, sed potestas; fuit honor, iniuria non fuit; sacramentum pietatis fuit, deitatis non fuit detrimentum; fuit reparatio salutis humanae, imminutio substantiae non fuit hoc divinae".

132 Sermo 147, 8, CCL 24B, 907.

133 Sermo 140ter, 3, CCL 24B, 856: „Nascens ergo Christus non invenit in diversorio locum, per quem omnis creatus est locus; et velut peregrinus nascitur, qui totius orbis est dominus, ut nos caelestis patriae faceret esse municipes".

134 Por. Sermo 148bis, 2, CCL 24B, 924: „Nascitur itaque, nascitur Christus non necessitate vivendi, sed voluntate salvandi. Nascitur inter mortuos, qui vitam donat mortuis".

135 Por. tamże: „Nec poterat nisi novo ordine adventare de caelo, qui vetustum mortis destruere veniebat imperium”.

${ }^{136}$ Por. tamże: „Nascitur ab intacta femina Christus, quia fas non erat, ut virtus per voluptatem, castitas per luxuriam, per corruptionem incorruptio nasceretur". 
nieważ ten nie mógł zbliżyć się do Boga. Ten, który był niewidzialny, aby zbawić rodzaj ludzki stał się widzialny ${ }^{137}$. Jego zbawcza misja nie mogłaby się spełnić, gdyby Syn Boży nie przyjął prawdziwej ludzkiej natury, gdyby nie został zrodzony przez pokorną swoją Służebnicę ${ }^{138}$.

2. Wyniesienie natury ludzkiej. To, co dla Boskiej Osoby Słowa było uniżeniem, dla ludzkiej natury stało się wywyższeniem. Dzięki wcieleniu człowiek nie tylko został wyzwolony spod jarzma śmierci, grzechu, cierpienia ${ }^{139}$, lecz również stał uczestnikiem boskiej natury ${ }^{140}$. W Chrystusie człowiek otrzymał przybrane Boże synostwo i dar nieśmiertelności ${ }^{141}$. Został obdarowany nowym Bożym życiem oraz uczestnictwem w niebieskiej chwale ${ }^{142}$. W Chrystusie, stwierdza Chryzolog, Bóg zstąpił na ziemię, aby człowiek mógł wstąpić do nieba ${ }^{143}$.

Biskup Rawenny, aby wyrazić zbawczą aktywność Bożego Słowa przyjmującego ludzką naturę, posługuje się następującymi czasownikami: recreare ${ }^{144}$, redimer $e^{145}$, redintegrare ${ }^{146}$, redonare ${ }^{147}$, reformare ${ }^{148}$, reducere ${ }^{149}$, reparare ${ }^{150}{ }^{\prime}$. Bogate słownictwo pozwoliło Mu lepiej wyrazić zbawcze skutki wydarzenia wcielenia.

Jak już to wcześniej zostało powiedziane, Piotr Chryzolog kontempluje wcielone Słowo w świetle tajemnicy stworzenia. Taka perspektywa umożliwiła

${ }^{137}$ Por. Sermo 140ter, 2, CCL 24B, 855: „Venit ad faciem tuam, o homo, quia tu ad eius faciem pervenire non poteras; et qui erat invisibilis, factus est pro tua redemptione visibilis".

138 Por. Sermo 148bis, 2, CCL 24B, 924: „Neque vero poterat universitatis dominus formam servi suscipere, qua nos redimere disponebat, nisi eum peperisset ancilla. [...] Aut quomodo pro nobis sputamenta, palmas et crucem Dei filius sustineret, nisi se filium hominis praebuisset".

${ }^{139}$ Por. Sermo 148, 5, CCL 24B, 922: „Quem terrenum fecerat, fecit esse caelestem. Animatum humano spiritu, spiritum vivificat in divinum, et sic eum totum tollit in deum, ut in eo quod peccati, quod mortis, quod laboris, quod doloris, quod terrae est, nil relinquat".

${ }^{140}$ Por. Sermo 80, 9, CCL 24A, 496: „Filius Dei, virginis filio, Deus homini, divinitas carni contulit, quod semper cum patre possedit et spiritu”; Sermo 144, 7, CCL 24B, 883; „Deus erat in Christo mundum reconcilians sibi: sibi utique, non alii. Hic ergo Deus, qui in Christo erat, regnum sibi dabat in Christo, et conferebat suscepto corpori, quod semper divinitate possederat".

${ }^{141}$ Por. Sermo 140bis, 5, CCL 24B, 852: „Intrat uterum, ut utero te reformet; nascitur, ut ad immortalitatem faciat te renasci; fit primogenitus, ut te divini generis praestet esse consortem”.

${ }^{142}$ Por. Sermo 145, 9, CCL 24B, 897: „Verbum caro factum est, ut hominis caro promoveretur in gloriam Dei, non ut Deus in carnis verteretur inuriam".

${ }^{143}$ Por. Sermo 142, 1, CCL 24B, 863: ,Audistis in terris Deum, in caelis hominem sacramento incomprehensibili collocari”.

144 Por. Sermo 80, 9, CCL 24A, 496.

145 Por. Sermo 148bis, 2, CCL 24B, 924.

146 Por. Sermo 140ter, 2, CCL 24B, 856; Sermo 148, 5, CCL 24B, 921.

147 Por. Sermo 131, 7, CCL 24B, 806.

148 Por. Sermo 140bis, 1, CCL 24B, 851; Sermo 143, 9, CCL 24B, 876.

149 Por. Sermo 64, 4, CCL 24A, 383.

${ }^{150}$ Por. Sermo 49, 3, CCL 24, 271; Por. Sermo 57, 6, CCL 24, 321; Por. Sermo 64, 2, CCL 24A, 381. 
mu nie tylko ukazanie wydarzenia wcielenia jako szczytu całej aktywności stwórczej, lecz również pozwoliła dostrzec zbawcze konsekwencje przyjęcia ludzkiej natury przez Odwieczne Słowo. Jak grzech pierwszych rodziców spowodował utratę stanu pierwotnej sprawiedliwości, skażenie natury ludzkiej, zniszczenie obrazu Bożego, tak przyjęcie ludzkiej natury przez Syna Bożego spowodowało odrodzenie człowieczeństwa, przywrócenie stanu sprawiedliwości pierwotnej, odnowienie Bożego obrazu. Jak można zauważyć, koncepcja recapitulatio, którą często posługuje się Chryzolog, umożliwiła mu, ukazanie wcielenia jako dzieła nowego stworzenia. W jednej z homilii znajdujemy na ten temat następujące słowa:

\begin{abstract}
„Ale zapytasz: dlaczego musiał Bóg się narodzić, skoro przecież mógł to uczynić także przez akt stwórczy? Dlaczego? Aby naturę, którą uczynił przez stworzenie, odnowić przez narodzenie, bo natura, która była przeznaczona do zrodzenia życia stała się sprawczynią śmierci. To właśnie spowodowało narodzenie, które powziął Chrystus. Narodzenie Stwórcy miało przynieść uzdrowienie naturze, a uzdrowienie natury miało znów udzielać życia jej wszystkim dzieciom" ${ }^{151}$.
\end{abstract}

3. Ewa i Maryja. Przyjście na świat Chrystusa - nowego Adama, pozwoliło Chryzologowi przyjrzeć się w nowym świetle Błogosławionej Dziewicy i podkreślić Jej wkład w zbawcze dzieło Syna. Kaznodzieja, porównując postacie Ewy i Maryi, podkreślił istniejące między nimi podobieństwa, jak również zaznacza zachodzące między nimi różnice: obydwie były dziewicami i do obydwóch niewiast przyszedł anioł. O ile Ewie ukazał się anioł upadły, o tyle Maryi objawił się dobry anioł ${ }^{152}$. Diabeł rozpoczął rozmowę z Ewą, aby dokonać dzieła zniszczenia człowieka ${ }^{153}$, natomiast anioł Gabriel rozmawia z Maryją, aby naprawić to, co ów pierwszy zły duch popsul ${ }^{154}$.

Zachowanie obydwu niewiast jest podobne: obydwie wierzą. O ile pierwsza wierzy kusicielowi, o tyle druga ufa Stworzycielowi. Ewa popełniając grzech, staje się przyczyną śmierci ${ }^{155}$, a Jej łono zostaje ukarane ${ }^{156}$. Ona sama zaś,

151 Sermo 143, 11, CCL 24B, 878, thum. W. Kania, TMB 2., Niepokalanów 1981, 138.

152 Por. Sermo 148, 5, CCL 24B, 921: ,ad virginem diabolus venerat, venit angelus ad Mariam, ut quod malus deiecerat angelus, bonus angelus adlevaret. Perfidiam suasit ille, hic fidem; suasori credit illa, ista credit auctori".

153 Por. Sermo 142, 1, CCL 24B, 863: „Agit, agit cum Maria angelus de salute, quia cum Eva angelus egerat de ruina".

154 Por. Sermo 148, 5, CCL 24B, 921: ,ut quod malus deiecerat angelus, bonus angelus adlevaret".

155 Por. Sermo 64, 2, CCL 24A, 380: „Et quia mulier fuerat mali caput, causa mortis, agit, ut ante crimen diluat quam veniam largiatur".

156 Por. Sermo 140, 4, CCL 24B, 847: „Quia in quibus Eva maledicta puniebat viscera, nunc in illis gaudet, honoratur, suspicitur Maria benedicta. Et facta est vere nunc mater viventium per gratiam, quae erat ante mater morientium per naturam". 
zamiast być matką żyjących, staje się matką umarłych, ponieważ poprzez nią śmierć weszła na świat ${ }^{157}$. Maryja natomiast, wyrażając swoją wiarę i przyjmując Bożą łaskę, staje się matką żyjących ${ }^{158}$. Łono Maryi, w przeciwieństwie do łona Ewy, zostaje pobłogosławione przez Boga. Maryja nie doświadcza bólów porodu, a rodząc Życie, staje się służebnicą zbawienia. Dzięki Jej pośrednictwu wszystko zostaje zbawione ${ }^{159}$.

\section{Narodzenie Chrystusa jako kategoria interpretacji dziejów. Warto} zauważyć, że narodzenie Chrystusa zostało przedstawione przez jako punkt zwrotny w dziejach ludzkości. Wydarzenie to, zdaniem Chryzologa, stanowi moment kulminacyjny, dzielący historię świata na dwa okresy: przed i po Chrystusie, nadający dziejom ludzkości prawdziwy sens i znaczenie ${ }^{160}$. Wcielenie staje się kategorią hermeneutyczną, w świetle której biskup Rawenny odczytuje i interpretuje historię. Interpretowane w takiej perspektywie historyczne fakty stają się szczególnymi miejscami objawienia planu zbawczego planu Boga, który prowadzi ludzkość poprzez poszczególne epoki do pełni czasów. Historia rodzaju ludzkiego rozpatrywana od chwili pojawienia się człowieka aż do momentu przyjścia Mesjasza na świat, jawi się jako czas oczekiwania na Jego nadejście. Prawdziwym sensem i celem Bożego działania na przestrzeni wieków jest przygotowanie ludzkości do przyjęcia Zbawiciela $^{161}$.

To przygotowanie polega na nieustannym i stopniowym objawianiu miłości Boga do człowieka, oraz na uwalnianiu człowieka ze strachu i niewolniczej bojaźni ${ }^{162}$. Wszechmocny wkracza w bieg ludzkiej historii, aby człowiek nauczył się Go kochać i aby oddawał Jemu cześć z miłością a nie z bojaźnią.

„Oto dlaczego powołuje Abrahama spośród pogan, nadaje mu nowe imię, czyni go ojcem w wierze, towarzyszy mu w drodze, chroni go przed obcokrajowcami, obdarowuje go darami, zaszczyca go sukcesami, związuje się z nim obietnicami, wybawia go z niebezpieczeństw, uwodzi gościną, obdarowuje nieoczekiwanym potomstwem, aby, napełniony tak licznymi darami, pociągnięty przez tak wielką

157 Por. Sermo 99, 5, CCL 24B, 610: ,ut sicut per Evam venit ad omnes mors, ita per Mariam rediret omnibus vita".

158 Por. Sermo 140, 4, CCL 24B, 847: „Et facta est vere nunc mater viventium per gratiam, quae erat ante mater morientium per naturam".

159 Por. Sermo 143, 4, CCL 24B, 873: „Hanc gratiam detulit angelus, accepit virgo salutem saeculis redditura".

${ }^{160}$ Por. Kochaniewicz, La Vergine Maria e la pienezza dei tempi nel mistero dell'Incarnazione secondo san Pietro Crisologo, VoxP 19(1999) t. 36-37, 323-325.

161 Por. Sermo 140bis, 4, CCL 24B, 852: „Merito ergo auctor temporum mundi tempus expectat, et erudiri saeculum longa aetate permittit, ut maturior mundus restauratorem suum vel sero reciperet, qui ante rudis suum capere non valuit Creatorem".

162 Por. Sermo 147, 4, CCL 24B, 911. 
słodyczą Bożej miłości, nauczył się kochać Boga, bez bojaźni, oddawać Jemu cześć z miłością pozbawioną strachu"163.

W podobnej perspektywie zostaje przedstawione życie Mojżesza. Boska obecność i towarzyszenie, obfitość boskich darów Jemu udzielonych, pomoc i wsparcie podczas wędrówki do Ziemi Obiecanej, są widocznymi znakami Bożej miłości, której jedynym celem jest wzbudzić w sercu sługi Pańskiego odpowiedź przenikniętą miłością ${ }^{164}$.

Pełnię czasów charakteryzuje wymiar uniwersalny, który sprawia, że zbawienie nie ogranicza się do narodu wybranego, lecz rozciąga się również na pogan. Dlatego też Bóg przygotowuje na przyjęcie Mesjasza nie tylko Izraelitów, lecz również i pogan. Bóg wzbudza w sercach tych ostatnich pragnienie widzenia Go. Kult pogańskich bożków, byłby, zdaniem Piotra Chryzologa, właśnie tego pragnienia wyrazem ${ }^{165}$.

Dokonana analiza kazań św. Piotra Chryzologa upoważnia do wyrażenia następujących wniosków. Przedstawiona w homiliach nauka o wcieleniu jest ze wszech miar interesująca, zawierająca wiele nowych i oryginalnych wątków.

Biskup Rawenny, komentując tajemnicę wcielenia, wielokrotnie podkreśla prawdę o boskości Syna odwiecznie zrodzonego i współistotnego Ojcu, który przyjął człowieczeństwo w łonie Dziewicy Maryi. Bóg przygotował Maryję do macierzyńskiej roli, dokonując Jej uświęcenia. Ubogacona boskimi darami pokorna Służebnica Pańska doświadczyła w swoim łonie przedziwnego wcielenia, zanim wypowiedziała swoje fiat. Poczęcie Jezusa zostało przedstawione w niemniej oryginalny sposób: jako zaślubiny pomiędzy Bogiem a człowiekiem. Maryja, sponsa Dei, sponsa Christi, zostaje poślubiona przez Boskiego Oblubieńca. Natomiast ziemskie narodziny Zbawiciela ukazane zostały jako objawienie się zbawczej mocy Boga, która sprawia, że dziewica stała się matką, a będąc matką nie utraciła swojego dziewictwa.

Należy zauważyć, że zarówno tematy uświęcenia Maryi, uprzedniego poczęcia Jezusa, jak również tytuły maryjne sponsa Dei, sponsa Christi są niezna-

163 Por. Sermo 147, 4, CCL 24B, 911: „Hinc est quod Abraham vocat de gentibus, auget nomine, patrem fidei facit, comitatur viam, inter exteros servat, ditat rebus, honorat triumphis, promissis obpignerat, eripit iniuriis, hospitalitate blanditur, mirificat germine disperato, ut tot repletus bonis, tanta divinae illectus dulcedine caritatis, Deum diligere disceret, non timere, amando colere, non pavendo".

164 Por. tamże.

165 Por. Sermo 147, 7, CCL 24B, 912: „Hinc est quod amor, qui cupit videre Deum, et si non habet iudicium, habet tamen studium pietatis. [...] Denique et ipsi gentiles ob hoc simulacra finxerunt, ut in ipsis erroribus oculis cernerent quod colebant". 
ne literaturze łacińskiej, pojawiają się one wyłącznie w tradycji wschodniej. Chryzolog jawi się jako jedyny Ojciec Kościoła Zachodniego, prezentujący powyższe argumenty w kazaniach głoszonych po łacinie.

Wydarzenie wcielenia zostało wyrażone za pośrednictwem pewnych terminów, wśród których descensio podkreśla kenozę Syna Bożego, lecz również Jego trwanie w jedności z Ojcem. Wspomniana jedność zostaje podkreślona poprzez ideę podwójnych narodzin Chrystusa, która podkreśla, iż ziemskie narodziny Syna nie oddzielają Go od Ojca, co więcej, staje się epifanią, objawieniem owych odwiecznych narodzin.

Piotr Chryzolog, nauczając o tajemnicy wcielenia, koncentruje swoją uwagę na bóstwie Słowa Wcielonego. Nic więc dziwnego, że stosowana przez niego terminologia służy temu właśnie celowi: obronić prawdę o bóstwie Chrystusa wobec niebezpieczeństwa herezji ariańskiej. Należy stwierdzić, iż kazania charakteryzuje ubóstwo pojęć wyjaśniających zjednoczenie osobowe, co w okresie pomiędzy soborami w Efezie i Chalcedonie, na który przypada episkopat Chryzologa jest czymś trudno wytłumaczalnym. Inną słabą stroną chrystologii biskupa z Rawenny jest niedostatecznie wyjaśniona aktywność Ducha Świętego w momencie wcielenia. Brak satysfakcjonujących informacji na ten temat skłoniły R. Benericettiego do sformułowania hipotezy o obecności tzw. Geistchristologie w homiliach Złotosłowego biskupa. Kaznodziejski język biskupa Piotra cechuje bogactwo terminów i określeń, które umożliwiają wieloaspektowe spojrzenie na tajemnicę wcielenia, wydobywając nowe ukryte znaczenia tego wydarzenia: inhabitatio, consortium, indumentum, assumere, mixtio, commercium.

Inną cechą chrystologii Chryzologa jest jej apologetyczny wydźwięk. Kaznodzieja wyjaśniając tajemnicę Chrystusa, usiłuje obronić wiarę wiernych przed niebezpieczeństwem doktryny ariańskiej. Natomiast nie wydaje się, aby jego nauczanie było skierowane przeciwko nestorianom. Rzadkie, sporadyczne mówienie o duszy ludzkiej Chrystusa i posługiwanie się schematem Logos-sarx, bóstwo-ciato, zrodziło podejrzenie o tendencje apolinarystyczne Piotra Chryzologa. Dokładna analiza jego kazań, pozwoliła rozwiać sformułowane podejrzenia.

Innym aspektem charakteryzującym tajemnicę wcielenia jest jej wymiar zbawczy. Słowo stało się ciałem, aby zbawić rodzaj ludzki, zniszczyć imperium śmierci, wewnętrznie odnowić człowieka. Należy zauważyć, iż biskup Rawenny, posługując się ideą rekapitulacji odczytał wcielenie jako nowe stworzenie, osobę Chrystusa jako nowego Adama, a Maryję jako nową Ewę. Należy wreszcie podkreślić, iż tajemnica wcielenia jest interpretowana przez Chryzologa w perspektywie dziejów ludzkości. Wydarzenie to, nadaje prawdziwy sens historii człowieka, ukazując, w jaki sposób Bóg towarzyszył człowiekowi i przygotowywał go do pełni czasów, zapoczątkowanej przyjściem Zbawiciela. 
Reasumując, należy stwierdzić, iż tajemnica wcielenia przedstawiona przez Piotra Chryzologa, pomimo swoich słabości, posiada wiele wątków nowych i oryginalnych, godnych pogłębienia w odrębnym studium.

\title{
IL MISTERO DELL'INCARNAZIONE NEI SERMONI DI PIETRO CRISOLOGO
}

\author{
(Riassunto)
}

Il mistero dell'Incarnazione presentato nei sermoni di Pietro Crisologo, vescovo di Ravenna (380-450), occupa un posto importante, intorno al quale si svolge la riflessione teologica del Dottore della Chiesa. Tale mistero mette in rilievo il Verbo di Dio, generato dal Padre, consostanziale a Lui, che per la nostra salvezza assume la nostra natura umana nel grembo verginale di Maria. Tale concepimento viene spiegato come le nozze tra divinità e umanità, alle quali la sposa di Dio viene preparata tramite previa santificazione. Arricchita con i divini doni Maria percepisce il grande mistero che si svolge nel suo grembo: il Verbo si fa carne. Tale evento, però, avviene prima del „fiat” di Maria. Il Verbo, che si fa carne nel grembo verginale, opera in Maria l'unione di due realtà opposte: la vergine diventa madre e essendo madre non perde la sua verginità. Invece il parto verginale di Maria viene presentato nella prospettiva trinitaria, come manifestazione nel tempo della generazione eterna del Figlio dal Padre. Tale impostazione del discorso teologico di Pietro Crisologo, che mette in evidenza la divinità di Cristo, era condizionata dalla presenza dei seguaci della dottrina ariana, in Ravenna ai tempi del Crisologo.

Non sorprende perciò che tutta la terminologia, ricca di simboli, serva alla difesa della natura divina di Cristo. Questa impostazione rende che la sua cristologia come caratterizzata da una povertà delle espressioni che riguardano l'unità del soggetto. La dottrina del vescovo di Ravenna contiene anche altre debolezze. Tenendo conto che l'episcopato del Crisologo si svolge tra i due Concili di Efeso e di Calcedonia, il periodo in cui le controversie contro le dottrine di Nestorio e di Eutiche riecheggiano nella Chiesa, ci si aspetterebbe un adeguato riferimento nei suoi sermoni. Bisogna riconoscere, però, che le omelie non contengono tracce di tali polemiche, anzi, il loro linguaggio cristologico non è in grado di spiegare precisamente la unità delle nature nella persona di Cristo. Infine si deve aggiungere come non sufficientemente spiegata la funzione dello Spirito Santo nel mistero dell'Incarnazione.

Lo schema Logos-sarx usato nelle sue omelie e la trascuratezza dell'anima di Cristo hanno suscitato il sospetto che il Crisologo fosse un apollinarista. L'analisi attenta dei sermoni non ha confermato tali opinioni. Bisogna tener presente che il mistero dell'Incarnazione esposto dal Padre della Chiesa è caratterizzato da una forte dimensione soteriologica. Il Verbo si è fatto carne per la salvezza dell'umani- 
tà, per distruggere l'impero della morte, per un rinnovamento dell'uomo. Utilizzando il concetto di ricapitolazione, Pietro Crisologo ha riletto il mistero dell'Incarnazione come una nuova creazione, la persona di Cristo viene vista come nuovo Adamo, e la figura di Maria come nuova Eva.

Infine bisogna tener presente che la riflessione del Crisologo sul mistero dell'Incarnazione riguarda anche la storia dell'umanità. Questo evento imprime alla storia dell'uomo un senso vero, presentando il periodo prima della venuta di Cristo come una preparazione a tale evento.

Tale preparazione non si limita però solo al popolo eletto, ma si estende ai pagani. Anche loro sono stati chiamati ad accogliere il Messia. Riassumendo, bisogna notare che il mistero dell'Incarnazione presentato da Pietro Crisologo, è interessante e degno della nostra attenzione. Nonostante alcune mancanze, la sua dottrina contiene diversi aspetti molto originali che dovrebbero essere oggetto di uno studio pi approfondito. 